
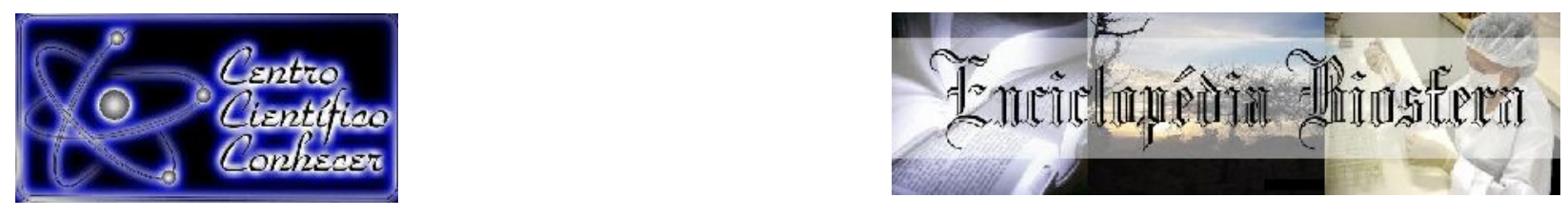

\title{
GESTATIONAL TROPHOBLASTIC DISEASE: CHORIOCARCINOMA AND ITS TREATMENT
}

Nayane Peixoto Soares ${ }^{1,2,3^{*}}$, Vanessa de Sousa Cruz ${ }^{4}$, Leandro Lopes Nepomuceno ${ }^{1}$, Vanessa de Souza Vieira ${ }^{1}$, Eugênio Gonçalves de Araújo ${ }^{5}$

1. Discente do Programa de Pós-Graduação em Ciência Animal (PPGCA), nível doutorado, da Escola de Veterinária e Zootecnia (EVZ) da Universidade Federal de Goiás (UFG), (nayane.peixoto@gmail.com) Goiânia-Brasil;

2. Docente da Universidade Estadual de Goiás (UEG), Anápolis-Brasil;

3. Docente da Faculdade Metropolitana de Anápolis (FAMA), Anápolis-Brasil.

4. Pesquisadora do Programa Nacional de Pós-Doutorado do PPGCA, EVZ, UFG.

5. Docente da Universidade Federal de Goiás, Goiânia-Brasil.

Recebido em: 06/04/2019 - Aprovado em: 10/06/2019 - Publicado em: 30/06/2019 DOI: 10.18677/EnciBio_2019A74

\begin{abstract}
Gestational trophoblastic disease is a general term used to designate changes originating from the abnormal proliferation of the trophoblast, which includes the hydatidiform mole, invasive moles, placental site trophoblastic tumor and choriocarcinoma, among others less frequent. This revision aims to show gestational trophoblastic diseases, focusing on choriocarcinoma, besides presenting substances from plants tested in this cancer. Choriocarcinoma is formed by a proliferation of cytotrophoblasts and syncytiotrophoblasts, characterized by abnormal trophoblastic hyperplasia and anaplasia, absence of chorionic villi, hemorrhage and necrosis. The choriocarcinoma occurs after a hydatidiform mole in spontaneous abortions, ectopic pregnancies, and normal full-term pregnancies. Its occurrence is also described in men, originated from testicular germ cell tumors. In women, a preexisting hydatidiform mole, evaluation of elevate hCG levels not associated with pregnancy, ultrasonography and anatomopathological examination are important in the diagnosis. In most cases of choriocarcinoma and other gestational trophoblastic neoplasia, the treatment using chemotherapy drugs is the most used. Moreover, many isolated substances, identified and/or synthetized, from medicinal plants, have been tested and may be sources of future drugs to act directly or indirectly on treatment or prevention of these diseases. The results of recent research with plantderived molecules show inhibition mechanisms of cell proliferation and cell viability similar to those used in current regimes. This reveals the importance of continuing to carry out researches that present biochemical and molecular aspects of choriocarcinoma, such as action of treatment or prevention drugs, as well as further studies regarding substances with therapeutic potential and lower adverse effects.
\end{abstract}

KEYWORDS: Cancer, Gestational Trofoblastic Diseases, Embryology. 


\title{
DOENÇAS TROFOBLÁSTICAS GESTACIONAIS: CORIOCARCINOMA E SEU TRATAMENTO
}

\begin{abstract}
RESUMO
Doença trofoblástica gestacional é um termo geral para designar alterações originadas da proliferação anormal do trofoblasto, como mola hidatiforme, mola invasora, tumor trofoblástico de leito placentário e coriocarcinoma, entre outras. Essa revisão tem 0 objetivo apresentar as doenças trofoblásticas gestacionais, principalmente coriocarcinoma, além de discutir substâncias provenientes de plantas testadas nesse câncer. O Coriocarcinoma é formado por uma proliferação de citotrofoblastos e sinciciotrofoblastos e é caracterizado por hiperplasia trofoblástica anormal e anaplasia, ausência de vilosidades coriônicas, hemorragia e necrose. Geralmente ocorre em seguida a uma mola hidatiforme em abortos espontâneos, em gestações ectópicas e gestações normais. Sua ocorrência também é descrita em homens, originado por tumores derivados das células germinativas do testículo. Em mulheres, a preexistência de uma mola hidatiforme, presença de níveis tipicamente altos de hCG não pertinentes à gestação, ultrassonografia e exame anátomopatológico são importantes no diagnóstico. Nos casos de coriocarcinoma o tratamento farmacológico quimioterápico é o mais utilizado. Além disso, muitas substâncias isoladas, e/ou sintetizadas, provenientes de plantas medicinais, estão sendo testadas e podem ser fontes de futuras drogas para atuar isoladamente ou como adjuvantes no tratamento ou prevenção destas enfermidades. Pesquisas recentes com moléculas derivadas de plantas apresentam mecanismos de inibição da proliferação e viabilidade celular semelhantes aos de drogas utilizadas nos regimes atuais. Isso revela a importância das pesquisas que apresentem aspectos bioquímicos e moleculares do coriocarcinoma, como alvo de ação dos fármacos de tratamento ou prevenção e, ainda, a realização de mais estudos que contenham substâncias com potencial terapêutico e menor efeitos adversos.
\end{abstract}

PALAVRAS-CHAVE: Câncer, Doenças Trofoblásticas Gestacionais, Embriologia.

\section{INTRODUCTION}

Gestational trophoblastic disease (GTD) is a general term used to designate changes originating from the abnormal proliferation of the trophoblast, which includes the hydatidiform mole (partial and complete), invasive moles, placental site trophoblastic tumor and choriocarcinoma, among others less frequent (LURAIN, 2011). Some molar pregnancies are benign, but persistent GTD can have a malignant potential. The others, called gestational trophoblastic neoplasia (GTN), are malignant and differ in their degree of proliferation, invasion and dissemination. After the evacuation of a complete hydatidiform mole, an abortion, or a term pregnancy, the trophoblastic tissue may persist and progress to a neoplasia. The suspicion of diagnosis can occur through examination of human chorionic gonadotrophin (hCG) hormone levels, not associated with pregnancy (LURAIN, 2011; RAMILO et al., 2014).

The choriocarcinoma differ from other GTN and occurs after a hydatidiform mole in spontaneous abortions, ectopic pregnancies, and normal full-term pregnancies (SÁNCHEZ ABALOS et al., 2014). Its occurrence is also described in men, originated from testicular germ cell tumors (YAZGAN et al., 2013; SÁNCHEZ ABALOS et al., 2014). In women, a preexisting hydatidiform mole is important in the diagnosis of this neoplasia, and by evaluation of elevate hCG levels not associated with pregnancy, ultrasonography and anatomopathological examination. However, 
the tumor is not always associated to a previous molar pregnancy. Primary growth of the uterus may not occur, and infrequently, a uterine involution may occur and the mole may disappear only after metastasis, which favors late diagnosis. Choriocarcinoma is sensitive to chemotherapy and early diagnosis favors healing (JHAYYA et al., 1999).

Choriocarcinoma is considered very aggressive by its peculiar characteristics. The invasion in adjacent tissues is followed by necrosis and intensive bleedings. It is a highly vascularized tumor and often followed by metastasis due to trophoblast affinity for blood vessels, getting into circulation quickly. By hematogenous spread, it reaches lungs, vagina, ovaries, kidneys, central nervous system, and least frequent, retroperitoneal space and lymph nodes (REGO et al., 2010; YAZGAN et al., 2013; RAMILO et al., 2014).

In most cases of choriocarcinoma and other gestational trophoblastic neoplasia, the treatment using chemotherapy drugs is the most used. Moreover, many isolated substances, identified and/or synthetized, from medicinal plants, have been tested and may be sources of future drugs to act directly or indirectly on treatment or prevention of these diseases.

In this regard, this revision aims to show normal aspects of trophoblastic formation, gestational trophoblastic diseases resulting from abnormal proliferation of tissues, focusing on choriocarcinoma, besides presenting substances from plants tested in this type of cancer.

\section{GESTATIONAL TROPHOBLASTIC DISEASE}

Gestational trophoblastic disease (GTD) is a spectrum of abnormal trophoblastic proliferations. It covers the following clinical pathological forms: partial or complete hydatidiform mole, placental site nodule, exaggerated placental site, invasive mole, choriocarcinoma, placental site trophoblastic tumor and epithelioid trophoblastic tumor. The term "gestational trophoblastic neoplasia" (GTN) is applied to these last four conditions, which may progress, invade, metastasize, and lead to death if not treated (LURAIN, 2010; LURAIN, 2011; STEVES et al., 2015; TEMPFER et al., 2016).

Trophoblastic cells have regulatory mechanisms that prevent neoplastic growth, but insufficient control of these mechanisms may allow the development of such complications. The main symptoms are bleeding, enlarged uterus, absent or abnormal embryo/fetus, grape-like placental villi with increased volume, among others (LURAIN, 2010; STEVES et al., 2015). The elevated serum level of $\beta$-hCG in non-pregnant women is characteristic of these conditions, which may present varied clinical signs such as uterine bleeding, hyperthyroidism and corpus luteum cysts related to elevation of hormones level. GTNs are highly vascularized tumors, as a consequence they are susceptible to metastasis and are detectable by vascular duplex ultrasound (STEVES et al., 2015).

The morphological classification of GTD by the World Health Organization (WHO) is based in presence and absence of villi. Complete hydatidiform moles $(\mathrm{CHM})$, partial hydatidiform moles (PHM) and invasive moles (IM) are classified as villous GTD. Placental site nodule (PSN), exaggerated placental site (EPS), choriocarcinoma (CC), placental site trophoblastic tumor (PSTT), epithelioid trophoblastic tumor (ETT), are classified as non-villous DTG (Table 1) (EL-HELW et al., 2009; TEMPFER et al., 2016). 
TABLE 1 - Gestational Trophoblastic Diseases presented according to morphological, clinical and pathological aspects, based in World Health Organization (WHO) classification.

\begin{tabular}{|c|c|c|}
\hline \multicolumn{3}{|c|}{ GESTATIONAL TROPHOBLASTIC DISEASES } \\
\hline \multirow[t]{3}{*}{ Villous } & \multirow[t]{3}{*}{ Molar pregnancy } & Partial Hydatidiform Moles (PHM) \\
\hline & & Complete Hydatidiform Moles (MHC) \\
\hline & & Invasive Moles (IM) - malignant \\
\hline \multirow[t]{5}{*}{ Non-villous } & \multirow{2}{*}{$\begin{array}{l}\text { Benign non-molar } \\
\text { lesions }\end{array}$} & Exaggerated Placental Site (EPS), \\
\hline & & Placental Site Nodule (PSN) \\
\hline & \multirow{3}{*}{$\begin{array}{l}\text { Gestational } \\
\text { Trophoblastic } \\
\text { Neoplasia }\end{array}$} & Choriocarcinoma \\
\hline & & Placental Site Trophoblastic Tumor (PSTT) \\
\hline & & Epithelioid Trophoblastic Tumor (ETT) \\
\hline
\end{tabular}

Source: Adapted from Tempfer et al. (2016)

GTN may arise after uterine evacuation of a molar pregnancy, ectopic pregnancy, or abortion, as well as after normal full term or preterm birth. Therefore, it is also referred to as persistent trophoblastic disease. These lesions vary considerably in clinical-pathological behavior and in propensity for invasion and local metastases. Although a GTD can occur as pregnancy complications in women at any age, it is more common in teenage pregnancy or advanced maternal age (40-50 years). Early detection of GTN is important because the prognosis is favorable after treatment, due to chemotherapy sensitivity in most of these lesions (DHANDA et al., 2014).

Although the prognosis is currently considered favorable, GTD has historically been associated with significant morbidity and mortality. In the 1970s, molar pregnancy was often followed by severe bleeding and other medical complications, also early detection and effective uterine evacuation were not possible. For GTNs the condition was similar before the introduction of chemotherapy in their treatment 50 years ago. The mortality rate for invasive mole was about $15 \%$, frequently due to bleeding, sepsis, embolic phenomena or surgical complications. Choriocarcinoma had a mortality rate of almost $100 \%$ when there were metastases and about $60 \%$ when hysterectomy was performed in non-metastatic cases (LURAIN, 2010).

Currently, the survival rates in GTDs are 95 to $100 \%$ if the disease is not drug resistant (KOHORN, 2014). GTNs represent one of the most curable solid tumors, with a cure rate of $90 \%$, even in the presence of metastasis (LURAIN, 2010). This success is result of the inherent sensitivity of trophoblastic neoplasms to chemotherapy, provided that the effective use of hCG as a tumor marker for disease diagnosis and monitoring of therapy is carried out, referral of patients to medial doctors who have specialized knowledge in the management of these diseases, the identification of prognostic factors that predicts response to treatment and improves the individualization of therapy, and a combined treatment of chemotherapy, radiation and surgery in patients at higher risk (LURAIN, 2011; STEVES et al., 2015). 
The FIGO (International Federation of Gynecology and Obstetrics) staging system presents each GTD stage and its risk stratification works as basis for any indication to chemotherapy. The postoperative care is based on the current TNM (tumor-node-metastasis staging system) classification and should be performed in all surgically treated cases (EL-HELW et al., 2009; DHANDA et al., 2014; TEMPFER et al., 2016).

The incidence and etiological factors that contribute to development of GTD are difficult to characterize. Inconsistencies in case definitions, inability to adequately characterize the population at risk, lack of centralized databases, lack of well-defined control groups to compare possible risk factors and rarity of disease hinder the acquisition of reliable epidemiological data (LURAIN, 2010).

However, for Hydatidiform moles (HM), potential factors such as extreme maternal age (advanced or very young maternal age), a previous molar pregnancy and history of miscarriage (2 to 3 times increased risk of a molar pregnancy compared to women with no history of abortion) (LURAIN, 2010; BRAGA et al., 2014). It may be related to ethnicity, since the incidence in Asian women is twice as high as that reported for Caucasian women, and these women need more chemotherapy cycles and use of second-line drugs compared to Caucasian and African-American women for disease remission (BRAGA et al., 2014).

GTDs are the result of an aberrant gestation with abnormal karyotype due to incorrect fertilization, that will cause the abnormal proliferation of the trophoblast (STEVENS et al., 2015). In most cases of CHM, fertilization of an enucleated oocyte occurs through a spermatozoon that, after fertilization, duplicates its genetic material, forming a zygote with paternal nuclear genomes, not resulting in fetal formation, only the embryonic attachments (KAJII; OHAMA, 1977; FISHER; NEWLANDS, 1998). The etiology may also be due to an autosomal recessive disorder with biparental $\mathrm{CHM}$ (BiCHM), called familial recurrent hydatidiform mole. Thus, women with recurrent miscarriages may present mutations in NLRP7 gene (OMIM 609661) and less frequent in KHDC3 L gene (OMIM 611687). It is assumed that NLRP7 plays an important role in the regulation of maternal imprinting genes in oocytes (STEVES et al., 2015).

In contrast, cases of PHM are often caused by fertilization of a normal oocyte by two spermatozoa, which results in a triploid zygote, so genetic material from both parents that will form an anomalous fetus are present (STEVES et al., 2015). Because they are morphologically similar to DTGs, P57 KIP2 immunostaining is used to distinguish them. $\mathrm{P} 57^{\mathrm{KIP} 2}$ is expressed exclusively by maternal chromosomes and appears to be maternally and paternally methylated, which makes positive immunostaining in PHM and non-molar pregnancies, and negative in CHM (NGAN et al., 2003; STEVES et al., 2015). Alternatively, in situ hybridization, DNA ploidy analysis using flow cytometry or molecular genotyping may be performed to differ between both and non-molar hydropic abortions (FISHER; NEWLANDS, 1998; LURAIN, 2010; LURAIN, 2011; DUFFY et al., 2015).

There are no predictive markers for GTN. Routine hCG levels monitoring after GTD is necessary since it has a tendency to persist and progress to neoplasia. IM shows myometrium infiltration by $\mathrm{CHM}$ and non-PHM, or, in rare cases, in extrauterine sites such as vagina or lungs, after vascular dissemination. It differentiates itself from choriocarcinoma by having chorionic villi (STEVENS et al., 2015).

Both GTD and GTN can occur years after any pregnancy; in these circumstances, diagnosis is a challenge. Signs range from vaginal bleeding and 
dysmenorrhea to other nonspecific symptoms, such as nausea or hemoptysis. This causes a GTN to be diagnosed when the tumor has spread to different organs. Moreover, PSTT shows positive immunostaining for human placental lactogen (hPL) and other extravillous trophoblastic markers (STEVENS et al., 2015).

Determination of serum hCG levels is the most important aspect in treatment choice and duration. It is also used to evaluate the effectiveness of treatment and, in many cases, may be the only tangible parameter indicating trophoblastic disease. GTNs produce different forms of $h C G$ and thus, it is crucial to precisely determine them (EOH et al., 2015; TEMPFER et al., 2016).

Treatment for benign molar diseases consists of complete evacuation of the trophoblastic material from the uterine cavity. Suction Curettage performed under ultrasound guidance is used and, because of increased bleeding risk, red blood cells concentrates should be available during curettage. Uterine evacuation methods may be associated with an increased risk of GTN and a subsequent need for chemotherapy. Because of the risk of developing a persistent GTD (0.5-2\%), serum hCG levels should be checked weekly until having negative results. If hCG levels are negative in at least two consecutive tests, the likelihood of persistent postmolar disease will be less than 1: 3000 (SECKL et al., 2010). This means that additional monthly determination of hCG levels will no longer be required (BRAGA et al., 2014; TEMPFER et al., 2016).

Chemotherapy is needed to treat IM and other GTNs. The chosen drug for low-risk patients (FIGO score $<7$ - Table 2) is methotrexate or Dactinomycin on alternate days. The first is the most widely used and this therapeutic regimen has demonstrated a high rate of disease remission. High-risk patients (FIGO score $\geq 7$ ) are commonly treated with the EMA/CO regimen of multidrug adjuvant chemotherapy, such as radiation therapy and surgery. This treatment is the most widely accepted in the world and has resulted in better remission rates compared to other regimens already used and has avoided chemotherapy resistance. Chemotherapy is not required for low-risk patients who have undergone hysterectomy. Monitoring of hCG levels during and after treatment should be done according to the same standards used for molar diseases (LURAIN, 2011; BRAGA et al., 2014; STEVES et al., 2015; EOH et al., 2015; BOLZE et al., 2015).

These diseases predominantly affect women of reproductive age of all ethnic groups. Therefore, treatments should be chosen according to the desire for posterior fertility of each patient, since in some cases total hysterectomy may be an alternative ${ }^{36}$. Appropriate treatment and complete remission of GTD should be aimed to prevent malignant progression. However, diagnosis after miscarriage, preterm birth and full-term pregnancy should be accurate since the identification and classification of molar pregnancies is desirable due to a $15 \%$ risk of developing choriocarcinoma in $\mathrm{CHM}$ and $0,5 \%$ in PHM. The development of choriocarcinoma occurs when the abnormal mass of the trophoblast becomes tumoral and may generate metastases, particularly in the uterus, lungs, or brain (DUFFY et al., 2015).

\section{CHORIOCARCINOMA}

Choriocarcinoma (CC), also known as chorioepithelioma, is formed by a proliferation of cytotrophoblasts and syncytiotrophoblasts in various proportions and extensive vascularization (CHENG et al., 2012; MAK et al., 2013; TEMPFER et al., 2016). It consists of a GTN characterized by abnormal trophoblastic hyperplasia and anaplasia, absence of chorionic villi, hemorrhage and necrosis. Direct myometrial and vascular invasion may result in metastases in distant sites, most commonly in 
the vagina, pelvis, lungs, brain, kidney, liver, intestine, spleen, skin and fetus (LURAIN, 2010; MARTÍNEZ-ORDAZ et al., 2012; DHANDA et al., 2014; STEVES et al., 2015).

This neoplasia may occur in association with any type of pregnancy. Approximately $25 \%$ of cases are from abortion or ectopic pregnancy, $25 \%$ are associated with full-term or preterm pregnancy and $50 \%$ of cases arise from a persistent molar pregnancy, although only 2 to $3 \%$ of cases of $\mathrm{HM}$ progress for choriocarcinoma (LURAIN, 2010; STEVES et al., 2015). In general, $15 \%$ of choriocarcinomas that occur in the first trimester of pregnancy result from a complete hydatidiform mole (EL-HELW et al., 2009; LURAIN, 2010). However, they can occur after a long time lapse, when due to abortions or regular labours, even in the form of metastasis (DUFFY et al., 2015; ARANAKE-CHRISINGER et al., 2016). Rarely, they occur concomitantly to pregnancy (ARANAKE-CHRISINGER et al., 2016).

This choriocarcinoma index, which arises from a CHM, can be explained by the fact that this molar disease was associated with mutations in the $\mathrm{p} 57^{\mathrm{KIP} 2}$ maternal gene, located in the 11 p15 region (11p15.5 p57). Several or specific mutations such as aberrant methylation in the maternal chromosome 11 p15 are linked to growth retardation, hemihyperplasia and cancer, fetal macrosomia, midline abdominal wall defects and several other childhood tumors (PATERAS et al., 2009). This may explain the increased risk of choriocarcinoma in complete molar pregnancies compared to other molar diseases or pregnancies. Therefore, establishing the allelic imbalance of the gene for gene expression is important in the diagnosis of molar pregnancy in order to discern the risk of developing choriocarcinoma (DUFFY et al., 2015).

CC may still be of non-gestational origin, classified in two subcategories: first, a mixed germ cell tumor; Second, somatic carcinomas or adenocarcinomas, from poorly differentiated (pluripotent) cells, with histomorphology and immunophenotype of choriocarcinoma. These tumors show a worse prognosis than gestational ones and require more aggressive treatment (CHENG et al., 2012; ARANAKE-CHRISINGER et al., 2016). Of these types, some cases are described in the ovaries and testicles, endometriosis and other sites (TEMPFER et al., 2016). However, most cases are intrauterine and of gestational origin (CHENG et al., 2012).

When CC occurs in men, although rare, its prognosis is even worse (MARTÍNEZ-ORDAZ et al., 2012; FANG-JIANG et al., 2014). Testicles are their main site, they are mixed and may involute after metastasis, leaving only a scar (MARTÍNEZ-ORDAZ et al., 2012). Complete resection of the primary site and metastasis, followed by cycles of chemotherapy seem to have a better effect on remission (FANG JIANG et al., 2014).

Regarding gestational CC, it may occur intraplacental choriocarcinoma. The biological behavior and presence of intraplacental CC are variables, and range from a clinically silent focus, isolated within a macroscopically normal placenta, to maternal or infant metastatic form (JIAO et al., 2016), as already described in a cerebral teratocarcinoma of trophoblastic origin in a child (HERNÁNDEZ et al., 2012). When not metastatic, they may present maternal symptoms such as vaginal bleeding and obstetric or neonatal complications, which should be treated specifically. All cases are associated with high concentration of $\beta-h C G$ in blood serum and urine (JIAO et al., 2016).

The incidence of choriocarcinoma is 1 in 20,000 to 40,000 pregnancies (HSIEH et al., 2013), but these rates have declined over the past 30 years. In addition, data collection on the indices is difficult due to the rarity of this tumor and 
the difficulty in distinguishing it clinically from an invasive mole. The risk factors for its development are ethnicity (higher in Indian and Asian women), advanced maternal age and previous CHM. Currently, it appears to be an increased risk of CC in women with prolonged use of oral contraception (LURAIN, 2010). Although the disease incidence is not high, in cases of occurrence, there is a high rate of lung or brain metastases (HSIEH et al., 2013).

In general, the choriocarcinoma is highly malignant, necrotic, hemorrhagic, and invasive tumor. Vascular invasion and metastasis may occur even when the primary tumor is small (DHANDA et al., 2014). Primary symptoms and accommodation in the vagina are followed by dysfunctional uterine bleeding (TEMPFER et al., 2016). Hypervascular metastases may also show hemorrhage. Pulmonary metastases may be asymptomatic, as well as hepatic metastases, or cause hemoptysis, dyspnea, chest pain or pulmonary arterial hypertension. Tumor dissemination to the brain results in headaches, convulsions and either motor or sensorial deficits (DHANDA et al., 2014). Because its varied manifestations and similarities to other diseases, GTD or not, its recognition becomes difficult when it is not preceded by a molar disease (SILVA; SILVA, 2010).

The $\beta$-hCG levels are in general higher than $100.000 \mathrm{U} / \mathrm{L}$, which may indicate a diagnosis (LURAIN, 2010). However, these elevated levels also result in unspecific symptoms. Thus, in most case, the initial diagnosis is not based in clinical findings, but is done after metastasis or primary tumor resection. When suspecting of choriocarcinoma, its anatomopathological diagnosis is made based on the curettage content analysis, which is done by suction under ultrasound guidance, as in other GTNs. In these procedures, extensive hemorrhage is common, followed by a high risk of perforation and should be avoided, according to clinical case analysis (BRAGA et al., 2014).

Problems of specificities should also be considered, since there are many forms of the hCG hormone. For example, a woman suspected of having choriocarcinoma after miscarriage and elevated serum $\beta$-hCG levels, underwent chemotherapy. When laparoscopy was performed, there was no tumor, and nothing was considered in the urine test and in the serological tests with heterophilic antibodies. Thus, it confirmed the need to have an investigation based on pathological, clinical and molecular methods for an improved search in this tumor diagnosis (GONZÁLEZ AGUILERA et al., 2016).

Similar to the above-mentioned $\mathrm{p} 57^{\mathrm{KI} P 2}$ protein, the p53 protein from the tumor suppressor gene TP53, which plays an important role in cell cycle block, is overexpressed in choriocarcinoma cells, which indicates failure to suppress the cell cycle in trophoblast (MAK et al., 2013). In addition, in gestational cases, this tumor cells do not show genetic material of the patient, since it comes from concept cells (PATERAS et al., 2009). These characteristics may be useful in immunohistochemistry and molecular diagnosis.

In this regard, analysis by STR genetic markers may be useful to identify whether the choriocarcinoma is gestational or non-gestational and indicate which type of pregnancy caused this tumor. For example, if the tumor arose from a CHM, it will present only paternal alleles; from an PHM, it will be triploid with 2 paternal alleles and 1 maternal allele; and originated from a non-molar pregnancy, it will be diploid with maternal and paternal alleles (PATERAS et al., 2009). Also, the use of fluorescence in situ hybridization (FISH) ploidy test, or the combination of morphology, FISH and immunohistochemical staining for p57KIP2 as diagnostic optimization (DUFFY et al., 2015), provide clinically useful information, which is not 
available from histological examination, which is not always reliable in these cases (PATERAS et al., 2009).

Another aspect of the pathogenesis of choriocarcinoma and other GTDs is the fact that the p21-activated protein kinase 4 (PAK4), which promotes cell motility, was overexpressed in choriocarcinoma cell lines (JEG3 and JAR) and other GTD, promoting their proliferation, cell migration and better tissue invasion. This protein was also found in placenta tissues in the first trimester, but in a smaller amount when compared to full term placenta and to these diseases, a fact that explains the aggressive behavior of choriocarcinoma. It was also found out that hCG positively regulates PAK4 expression. Activation of PAK4 is PI3K/PKB-dependent, which means that this protein stimulates cell proliferation through its potentiating effect on cell cycle progression (ZHANG et al., 2011).

When diagnosing $C C$, the prognosis is favorable when the treatment is appropriate to the staging system, which is proposed by the World Health Organization, based on the FIGO table. This scoring system takes into account the patient's age, type of previous pregnancy, number of months of pregnancy interval, previous treatment, hCG levels, tumor size, site of metastases, number of metastases, and failure history of previous chemotherapy. Thus, determining nature of gestational CC is important for the prognosis and selection of initial treatment. However, the clinical evaluation is not always accurate, since the tumor may not have originated from previous gestation (PATERAS et al., 2009), besides cases of nongestational CC.

Staging after histological confirmation of $\mathrm{CC}$ is performed based on gynecological tests with palpation, transvaginal ultrasonography, chest and abdomen computed tomography scan, and brain magnetic resonance imaging. If metastasis is suspected, an FDG-PET/CT may be required. Hysterectomy is usually indicated when there is severe bleeding with risk of death, but it is not generally recommended, since manipulation of the uterus in surgery is associated with the hematogenous spread of tumor cells, which may lead to pulmonary metastasis (TEMPFER et al., 2016).

CC is highly sensitive to first-line chemotherapy called EMA-CO (etoposide, methotrexate, dactinomycin, vincristine, and cyclophosphamide) (POWLES et al., 2007). Chemotherapy regimens based on cisplatin are currently considered (HAN et al., 2012) because, as well as those based on paclitaxel, they also have less toxicity therapeutic effects than other first-line therapies (WANG et al., 2008). However, 5-25\% of patients with CC show insufficient responses to conventional chemotherapy (KAWAMURA et al., 2013; LIM et al., 2016a).

The relapse, in cases not responding to chemotherapy, shows a worse prognosis in comparison to treatment-sensitive cases. There is no prognostic scoring system for recurrent or refractory patients. WHO and FIGO scoring systems are used to classify high and low risk disease at baseline. Although these scoring systems include prognostic scores for prior treatment (up to six points), they have not been widely evaluated or validated for these rare patients (POWLES et al., 2007).

The majority of intraplacental CC or concomitant to pregnancy may result in fetoplacental tissue abortion during pregnancy due to the lack of effective chemopreventive drugs with no side effects of treatment in that period. Therefore, although survival rates are higher than $90 \%$, especially in cases sensitive to first-line chemotherapy (LIM et al., 2016a), the development of new agents is crucial for the increase of therapeutic value and reduction of treatment side effects for general cases of CC (LIM et al., 2016a; LIM et al., 2016b; LIM et al., 2016c). 


\section{EFFECT OF ANTIPROLIFERATIVE AND CYTOTOXIC SUBSTANCES ON CHORIOCARCINOMA}

Some plant-derived substances have been tested in vitro in choriocarcinoma cell lines. Among them, the following stand out:

- Apigenin: flavonoid extracted from vegetables and fruits such as onions, oranges and parsley. It has several functions in the suppression of inflammation, oxidation, and carcinogenesis (LIM et al., 2016b).

- Quercetin: one of the main dietary flavonoids found in various fruits and vegetables, including onions, apple skin, lettuce, cauliflower, peppers, celery and cocoa (LIM et al., 2016a).

- Chrysophanol: anthraquinone extracted from rhubarb, used in traditional Chinese medicine (LIM et al., 2016c).

- Luteolina: flavonoid present in various fruits and vegetables, such as celery, parsley, and broccoli (LIM et al., 2016d).

- Curcumin: polyphenol extracted from the rhizomes of turmeric (earth turmeric), a plant native to Asia (LIM et al. 2016e).

- Tubeimoside I: a triterpenoid saponin isolated from Bolbostemma paniculatum, a plant used in traditional Chinese medicine (HUANG et al., 2011).

In addition, vitexin, a lignan extracted from Vitex negundo, from Asia, was tested in vivo in tumor induction in rats, compared to in vitro effects (TAN et al., 2012).

These substances effects were evaluated on cell proliferation and migration; apoptosis, oxidative stress and mitochondrial membrane potential (MMP) and cell signaling proteins that influence the proliferation of tumor cells (HUANG et al., 2011; TAN et al., 2012; LIM et al., 2016b; LIM et al., 2016c; LIM et al., 2016d; LIM et al. 2016e). The anti-proliferative effects of the isolated molecule were also investigated in conjunction with pharmacological inhibitors of cell signaling pathways (LIM et al., 2016b) or combined with chemotherapeutic drugs such as cisplatin and paclitaxel (LIM et al., 2016c) and, also evaluated the pathological reduction of tumor in rats (TAN et al., 2012). The JAR cell line, from primary tumor, and JEG-3, originated from secondary tumor (LIM et al., 2016d), were used in all studies analyzed in this review.

In these studies, PCNA decreased by the effect of apigenin, quercetin, lutein and chrysophanol (only in JEG-3 cells), which shows that these substances decrease the viability of tumor cells. PCNA is a molecule present in the nucleus next to the DNA polymerase, responsible for regulating the cell cycle (LIM et al., 2016b; LIM et al., 2016c; LIM et al., 2016d; LIM et al. 2016e).

Neoplastic cells treated with apigenin, quercitin, lutein, chrysophanol, curcumin or vitexin underwent apoptosis confirmed by annexin $\mathrm{V}$ and propidium iodide staining, analyzed by flow cytometry (TAN et al., 2012; LIM et al., 2016b; LIM et al., 2016c; LIM et al., 2016d; LIM et al. 2016e). The nuclear fragmentation observed by tunnel reaction (red fluorescence), also indicating cell death occurred in apigenin, chrysophanol and curcumin treatments (LIM et al., 2016b; LIM et al., 2016c; LIM et al. 2016e).

Apigenin acts on choriocarcinoma cells by blocking the RTK (receptor tyrosine kinase), which acts on cell growth and proliferation. This, when blocked, inactivates the entire cell survival pathway regulated by PI3K (phosphoinositide-3kinases), proteins that activate several pathways capable of regulating cell 
metabolism, survival, growth and differentiation, and downstream other proteins of this pathway in cascade as AKT (cell homologous to v-Akt oncogene), P70S6K (ribosomal protein S6 kinase - 70Kd), which is overexpressed in tumors and S6 (ribosomal protein), which regulates gene transcription of survival, proliferation and migration proteins (LIM et al., 2016b).

However, this compound is also capable of activating ERK1/2 (extracellular signal-regulated kinases), which act in the anti-apoptotic pathways, by phosphorylating subsequent proteins, such as P90RSK (ribosomal protein S6 kinase - 90Kd), responsible for regulating gene expression of survival, proliferation and migration. Even though, according to other results compiled by the authors, the data obtained for apigenin indicated that inactivation of AKT and the activation of ERK $1 / 2$ MAPK signaling pathways (mitogen-activated protein kinases) stimulate induced cell death. The suspicion is that Bax activation and inactivation of Bcl2 also occur, i.e., mitochondrial proteins that promote depolarization of the mitochondrial membrane and cytochrome $\mathrm{c}$ outflow into the cytoplasm, activate the pro-apoptotic proteins caspases 3 and 9 (LIM et al., 2016b) (Figure 1).

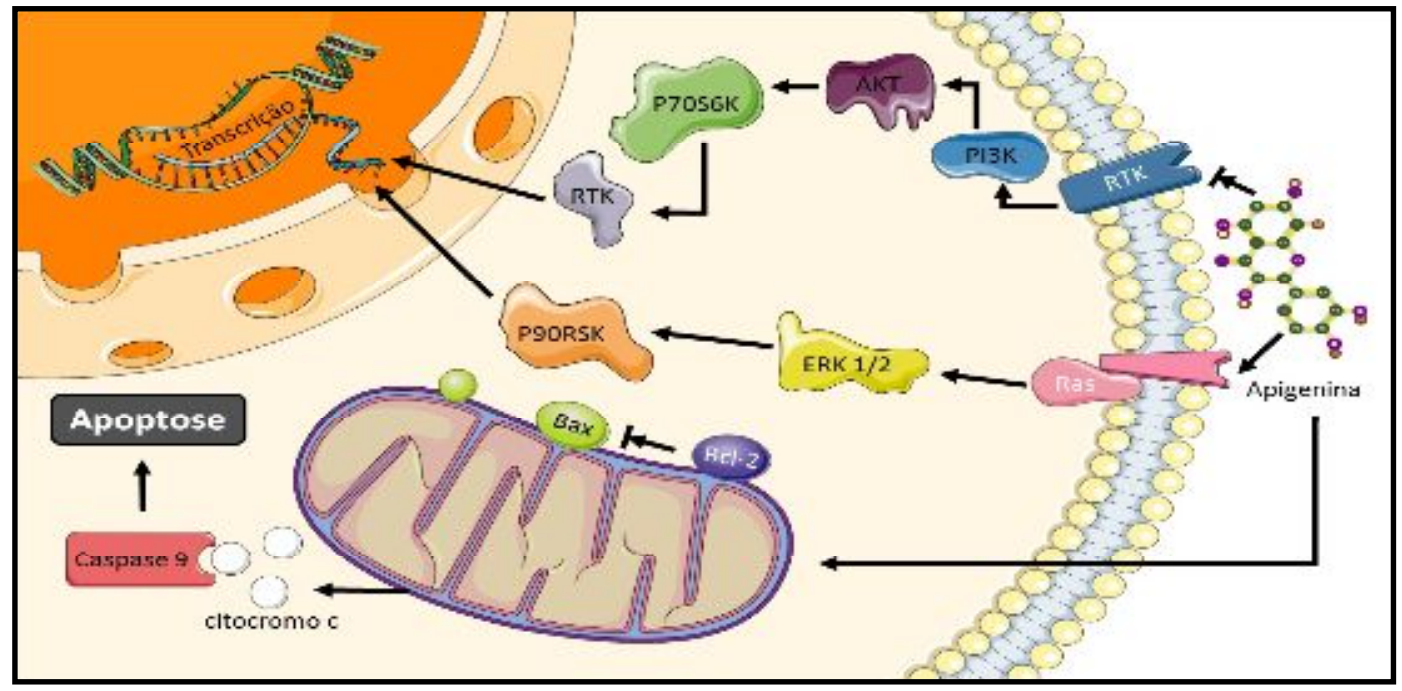

FIGURE 1 - Illustration of the current working hypothesis regarding the antiproliferative mechanism of apigenin targeting multiple signaling pathways in choriocarcinoma cells. Apigenin blocks the cell proliferation of choriocarcinoma lines by inhibiting PI3K/AKT and MAPK signaling and activation of ERK1/2 signaling.

Source: Adapted from Lim et al. (2016b)

In JEG-3 and JAR lines of choriocarcinoma, quercetin also inhibits the PI3K signal transduction pathway by down-regulation of AKT-p70S6K-S6. It further activates MAPK signaling pathways by means of Ras/Raf proteins (serine/threoninespecific protein kinases), which generates increased protein phosphorylation of ERK1/2 related to survival, $\mathrm{p} 38$ and JNK, related to apoptosis. Moreover, a downstream MAPK molecule, P90RSK, would also have been stimulated by quercetin in JAR and JEG-3. Intrinsic mitochondrial pathways apoptosis was also activated in choriocarcinoma cells by oxidative stress caused by the formation of ROS (reactive oxygen species) causing mitochondrial membrane depolarization and consequent release of cytochrome $\mathrm{c}$ into the cytoplasm, as a result of quercetin (LIM et al., 2016a) (Figure 2). 


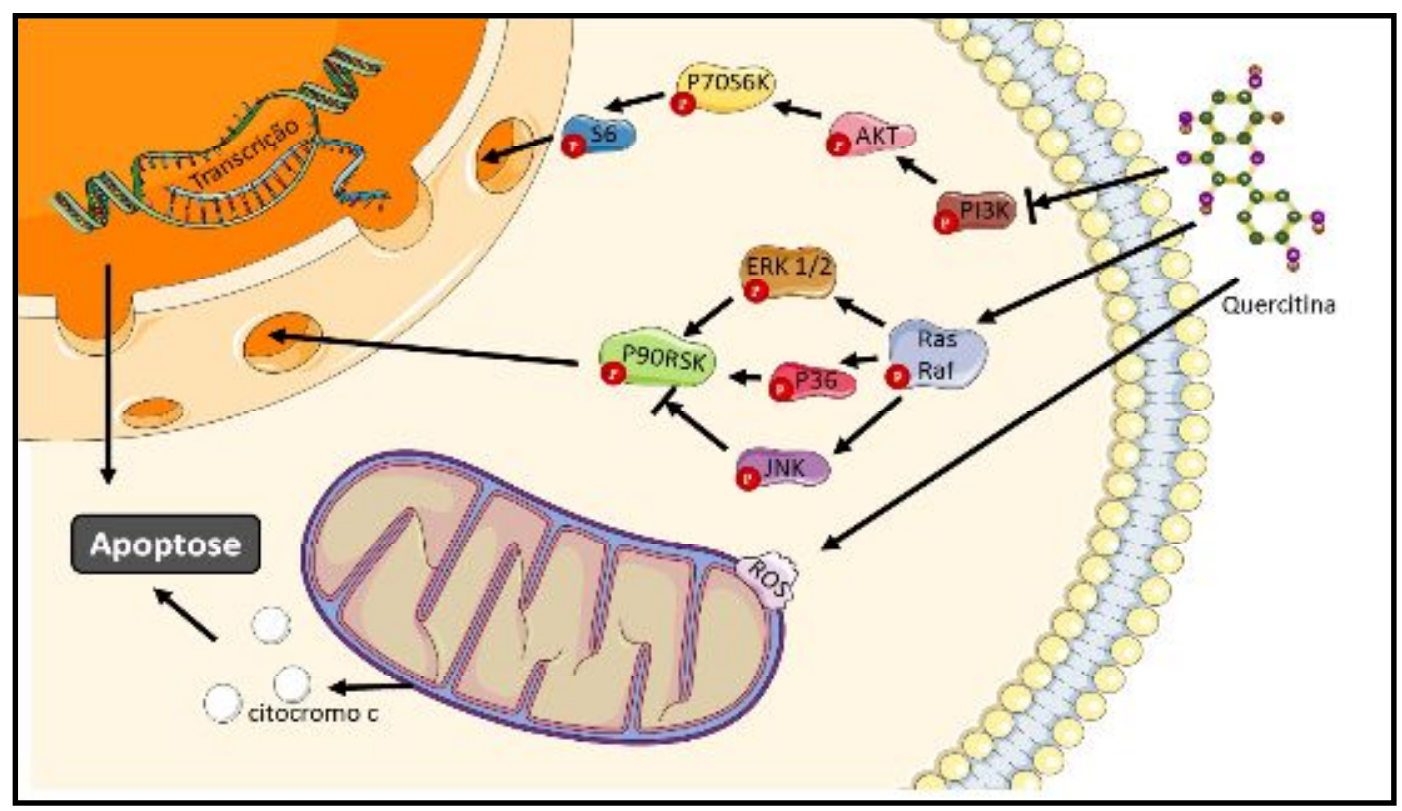

FIGURE 2 - Representative illustration of current hypothesis of antiproliferative mechanism induced by quercetin in choriocarcinoma cells, with multiple signaling pathways scheme.

Source: Adapted from Lim et al. (2016a)

A similar effect was observed in choriocarcinoma cells by curcumin. This molecule also caused intrinsic apoptosis mediated by ERK1/2 and JNK in MAPK pathways, inhibiting the PCNA protein related to cell survival and activating apoptosis-linked c-Jun and c-Fos proteins in JAR and JEG; also by reduction of antiapoptotic proteins Bcl-2 and Bcl-XL in JAR and increased expression of pro-apoptotic proteins including Bad, Bak, Bax, responsible for mitochondrial outer membrane permeability; by the increase of caspase 9 and mitochondrial membrane depolarization, sufficient events for apoptosis (LIM et al. 2016e) (Figure 3).

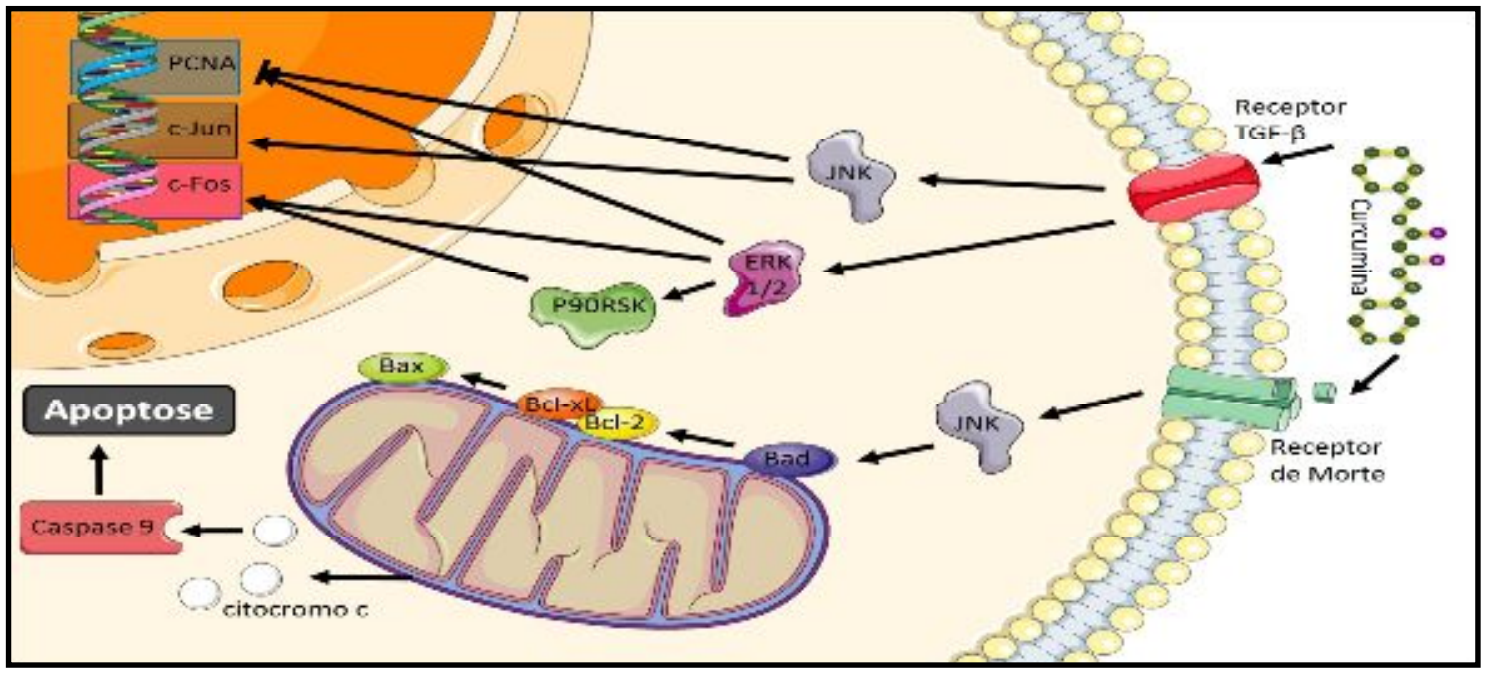

FIGURE 3 - Illustration of current hypothesis of antiproliferative mechanism induced by curcumin in choriocarcinoma cells, with multiple signaling pathways.

Source: Adapted from Lim et al. (2016e)

This was also the case in choriocarcinoma cells treated with chrysofuran. This compound produced antiproliferative effects, reducing cell viability and inducing intrinsic apoptosis, through ROS production, decrease in PMM, and cascade 
signaling mechanisms of ERK $1 / 2$ and PI3K-AKT in JEG-3 cells. Moreover, the inhibitory effects of chrysophanol were more efficacious when combined with cisplatin and paclitaxel, suggesting that such compound may be an important component of multi-agent regimens for the treatment of choriocarcinomas (LIM et al., 2016c) (Figure 4).

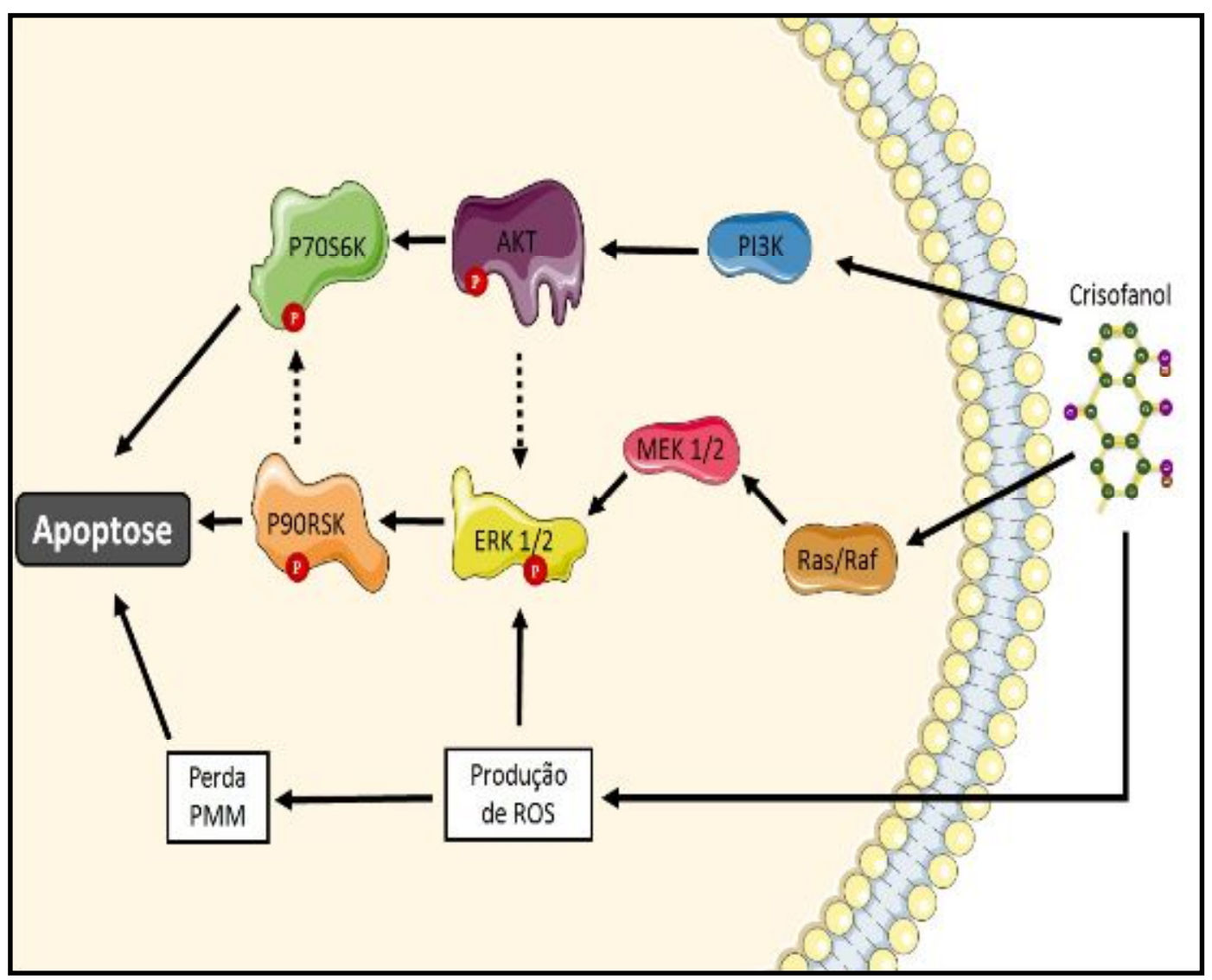

FIGURE 4 - Illustration of current hypothesis of antiproliferative mechanism induced by chrysophanolol in choriocarcinoma cells, with a scheme of different signaling pathways.

Source: Adapted from Lim et al. (LIM et al., 2016c)

Tubeimoside I exert cytotoxicity in JEG-3 line and apoptosis by activation of p38 and inactivation of ERK1/2 and AKT (Figure 5). These may be related to inactivation of transcription factors NF-kB, which stimulates the synthesis of $\mathrm{Bcl} 2$ protein. This protein has anti-apoptotic function when acting in Bax protein sequestration, its decrease, therefore, increases the cytoplasmic levels of Bax. In turn, Bax interacts with mitochondria, which releases cytochrome c into cytosol, which activates caspase 9, that activates caspase 3 in these cells. Mitochondrial depolarization was also observed through the accumulation of $\mathrm{CA} 2+$ in the cytoplasm (HUANG et al., 2011). 


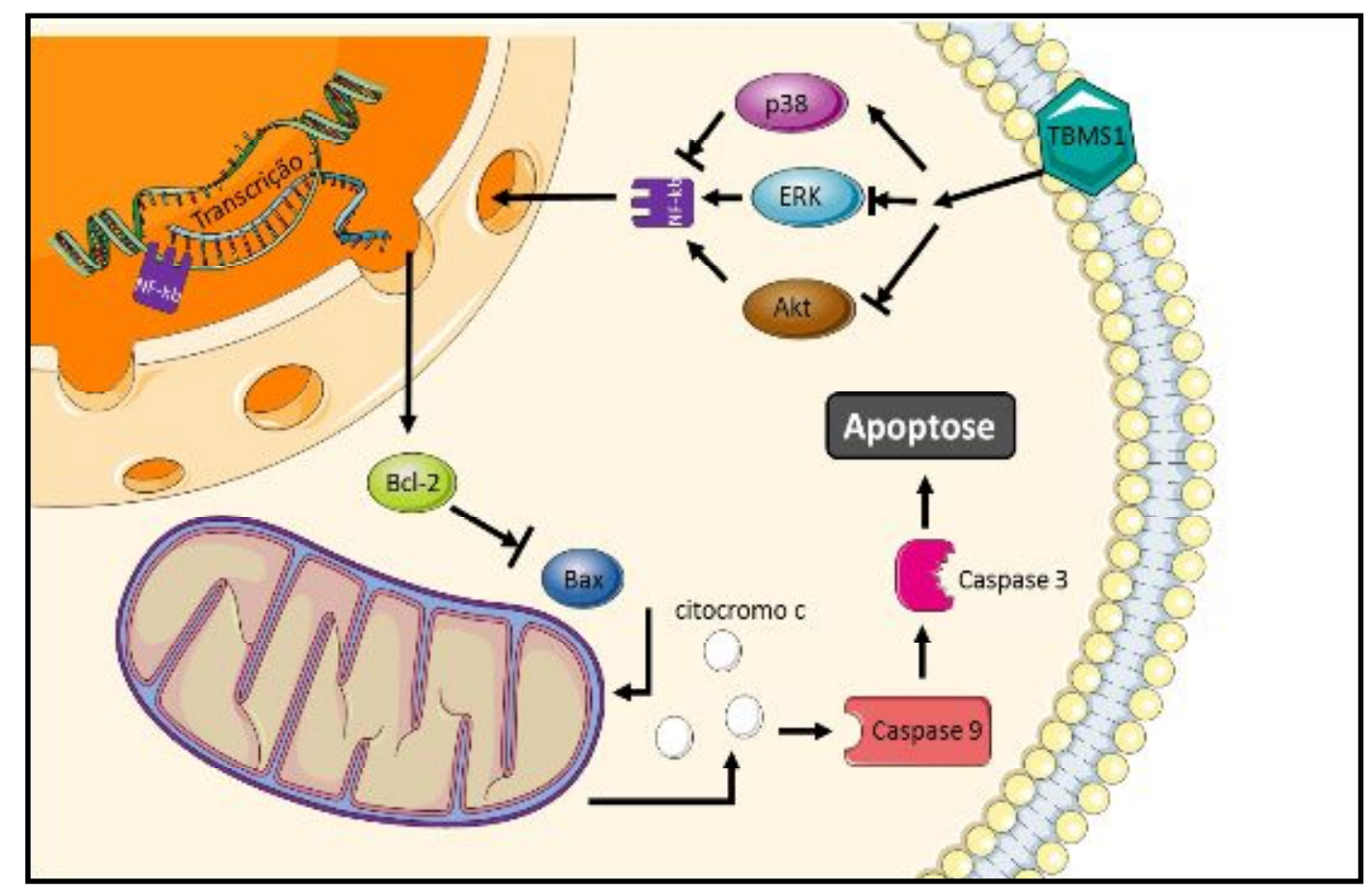

FIGURE 5 - Illustration of current hypothesis of anti-proliferative mechanism induced by the T-tube 1 (TBMS1) in choriocarcinoma cells targeting multiple signaling pathways

Source: Adapted from Huang et al. (2011)

Luteolin also has a cytotoxic effect on choriocarcinoma cells by inhibition through phosphorylation of AKT and p70S6K (Figure 6). The GSK3 $\beta$ (glycogen synthase kinase 3 beta) protein, which inactivates glycogen synthase, is another target downstream of AKT. However, the apoptotic effects of GSK3 $\beta$ are controversial because it plays a role in both pro-apoptotic and anti-apoptotic signaling pathways in dependent cellular environments. Significant inactivation of AKT and p70S6K suggests decrease in mTOR (mammalian target of rapamycin), which plays a key role in lipid synthesis, together with a downstream molecule SREBP. It acts as an intracellular steroid sensor. If the number of intracellular steroids is abundant, SREBP binds strongly SCAP to the endoplasmic reticulum. Under sterol depletion conditions, SREBP is released from the endoplasmic reticulum and transported into Golgi apparatus. Then, SREBP is cleaved twice, and the N-terminal fragments move to the nucleus. In the nucleus, SREBP binds to sterol regulatory elements (SREs) and induces the transcription of target genes encoding lipogenic enzymes. In cancer cells, lipid metabolism is altered abnormally, so several genes related to lipid synthesis are recognized as new targets for cancer therapy at transcriptional or posttranslational levels. Therefore, luteolin may act as a new therapeutic agent for patients resistant to classical chemotherapy for choriocarcinomas (LIM et al., 2016d). 


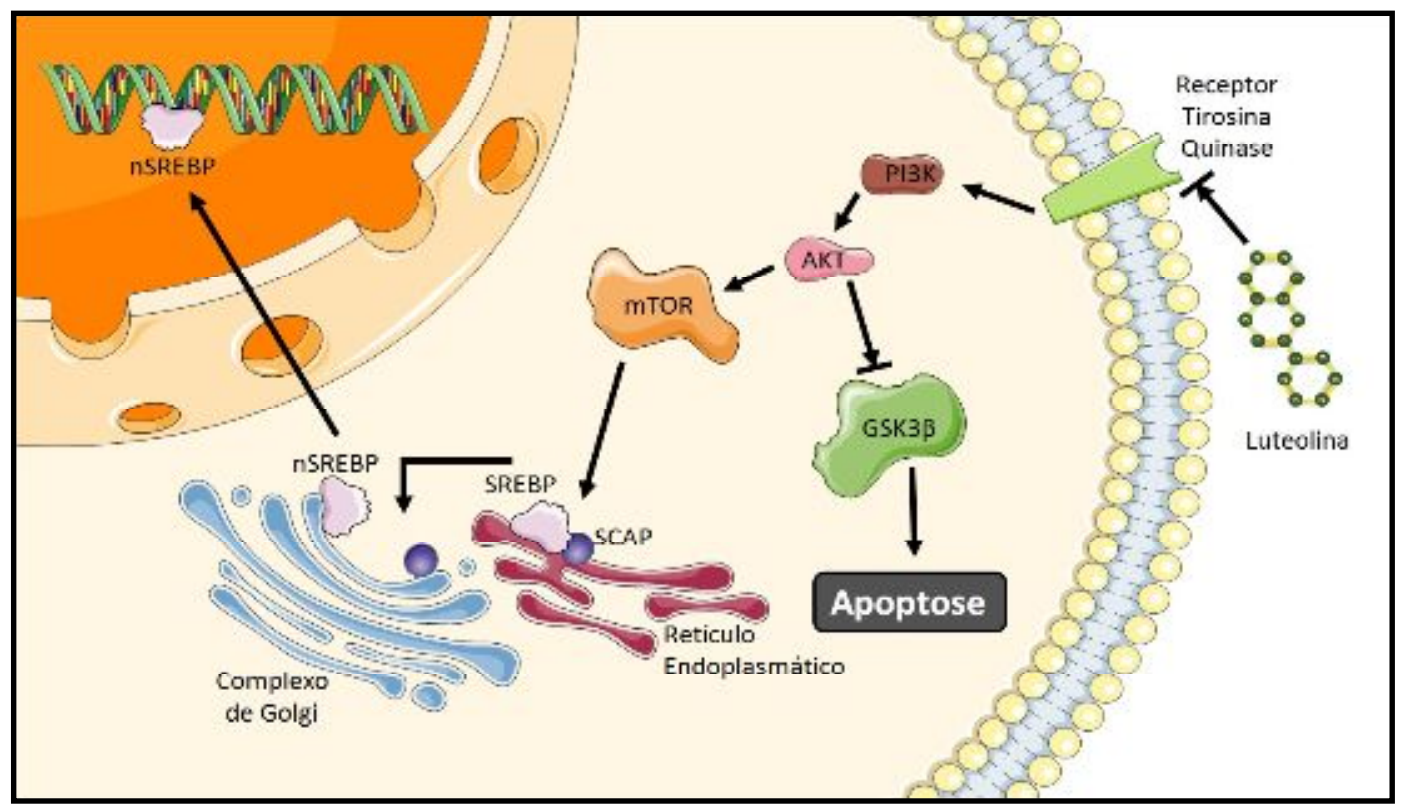

FIGURE 6 - Illustration of current hypothesis of antiproliferative mechanism of luteolin in choriocarcinoma cells. Luteolin acts on the inhibition of PISK/AKT cell signaling, as well as on the mTOR -SREBP axis, altering lipid metabolism.

Fonte: Adapted from Lim et al. (2016d)

Luteolin and chrysophanol presented different effects in the two choriocarcinoma lines (JEG3 and JAR) (LIM et al., 2016c; LIM et al., 2016d). This can be explained by the fact that these lineages have different characteristics, such as the main one of which is the origin. JAR cells derive from a placental primary tumor and JEG3 cells are from a clonal lineage of this secondary tumor in the brain (LIM et al., 2016d). The inhibitory effects of chrysophanol on cancer cells were even more effective when combined with cisplatin and paclitaxel, suggesting that this substance may be an important component of multi-agent regimens for the treatment of choriocarcinomas (LIM et al., 2016c).

Vitexin acts on the cell by inhibiting Bcl-2 protein and the mTOR signaling pathway, enhancing expression of caspase-3, promoting apoptosis. This substance was also tested on tumor induced in rats. After eight days of treatment, the tumor had its growth reduced by the effect of vitexin and the pathological test revealed necrosis and hemorrhages in tumor tissues, besides decreasing hCG levels in rats, due to the effect of this substance (TAN et al., 2012).

Finding cell signaling pathways that regulate carcinogenesis and metastasis is important for effective chemotherapy, to control the proliferation and survival of cancer cells, as well as the growth, metastasis, and apoptosis of tumor cells ${ }^{53}$. The substances tested in the pathways presented here show the viability of developing alternatives to treatments currently used in choriocarcinoma and other GTD, aiming to be more effective and present fewer adverse effects to patients with choriocarcinoma (LIM et al., 2016d).

\section{FINAL CONSIDERATIONS}

The trophoblast has its origin in the first cellular embryonic differentiation, in the compaction initiating the blastulation process. Its development takes place during the formation of placenta, being part of it and acting in the exchange of maternal-fetal nutrients. This structure, which constitute the fetal part of the placenta has in its 
formation the intense proliferation and the capacity for tissue invasion, and its abnormal development may originate malignant or benign gestational trophoblastic diseases. Among malignant GTD, choriocarcinoma is highly invasive, but sensitive to chemotherapy. Currently, it has been widely studied and efforts have been devoted to testing substances that act as alternatives or adjuvants to conventional chemotherapeutic drugs.

The results of recent research with plant-derived molecules show inhibition mechanisms of cell proliferation and cell viability similar to those used in current regimes. This reveals the importance of continuing to carry out researches that present biochemical and molecular aspects of choriocarcinoma, such as action of treatment or prevention drugs, as well as further studies regarding substances with therapeutic potential and lower adverse effects.

\section{REFERENCES}

ARANAKE-CHRISINGER, J., HUETTNER, P. C., HAGEMANN, A. R., PFEIFER, J. D. Use of short tandem repeat analysis in unusual presentations of trophoblastic tumors and their mimics. Human pathology, v. 52, p. 92-100, 2016. Disponível em: < https://www.sciencedirect.com/science/article/pii/S004681771600037X/> doi: 10.1016/j.humpath.2016.01.005

BOLZE, P. A., ATTIA, J., MASSARDIER, J., SECKL, M. J., MASSUGER, L., et al. Formalised consensus of the European Organisation for Treatment of Trophoblastic Diseases on management of gestational trophoblastic diseases. European Journal of Cancer, v. 51, n. 13, p. 1725-1731, 2015. Disponível em: < https://www.sciencedirect.com/science/article/pii/S0959804915004943> doi: 10.1016/j.ejca.2015.05.026

BRAGA, A., OBEICA, B., MORAES, V., DA SILVA, E. P., AMIM-JUNIOR, J. et al. Doença trofoblástica gestacional. Revista Hospital Universitário Pedro Ernesto, v. 13, n. 3, 2014. Disponível em: < https://www.epublicacoes.uerj.br/index.php/revistahupe/article/view/12124 > doi: 10.12957/rhupe.2014.12124

CHENG, W. F., CHEN, I. H., KUO, K. T., TSENG, L. H., CHEN, C. A. Subcutaneous mass as the primary manifestation of gestational choriocarcinoma: A case report. Gynecologic oncology case reports, v. 2, n. 1, p. 11-13, 2012. Disponível em: < https://www.ncbi.nlm.nih.gov/pmc/articles/PMC3860779/>

doi: 10.1016/j.gynor.2011.10.004

DHANDA, S.; RAMANI, S.; THAKUR, M. Gestational trophoblastic disease: a multimodality imaging approach with impact on diagnosis and management. Radiology research and practice, v. 2014, p. 1-12, 2014. Disponível em: < https://www.hindawi.com/journals/rrp/2014/842751/abs/> doi: 10.1155/2014/842751

DUFFY, L., ZHANG, L., SHEATH, K., LOVE, D. R., GEORGE, A. M. The diagnosis of choriocarcinoma in molar pregnancies: a revised approach in clinical testing. Journal of clinical medicine research, v. 7, n. 12, p. 961, 2015. Disponível em: < https://www.ncbi.nlm.nih.gov/pmc/articles/PMC4625817/> doi: 10.14740/jocmr2236w

EL-HELW, L. M., COLEMAN, R. E., EVERARD, J. E., TIDY, J. A., HORSMAN, J. M. et al. Impact of the revised FIGO/WHO system on the management of patients with gestational trophoblastic neoplasia. Gynecologic oncology, v. 113, n. 3, p. 306-311, 
2009.

Disponível

em:

doi:

https://www.sciencedirect.com/science/article/pii/S009082580900078X>

10.1016/j.ygyno.2009.02.006

EOH, K. J., CHUNG, Y. S., YIM, G. W., NAM, E. J., KIM, S. et al. Role of surgical therapy in the management of gestational trophoblastic neoplasia. Obstetrics \& gynecology science, v. 58, n. 4, p. 277-283, 2015. Disponível em: < https://synapse.koreamed.org/DOlx.php?id=10.5468/ogs.2015.58.4.277> doi: 10.5468/ogs.2015.58.4.277

FANG JIANG, Y. X., FENG, F. Z., REN, T., CUI, Z. M., WAN, X. R. Clinical analysis of 13 males with primary choriocarcinoma and review of the literature. OncoTargets and therapy, v. 7, p. 1135, 2014. Disponível em: < https://www.ncbi.nlm.nih.gov/pmc/articles/PMC4074184/> doi: 10.2147/OTT.S62561

FIGO O. C. FIGO staging for gestational trophoblastic neoplasia 2000: FIGO Oncology Committee. International Journal of Gynecology \& Obstetrics, v. 77, n. 3, p. 285-287, 2002. Disponível em: < https://obgyn.onlinelibrary.wiley.com/doi/full/10.1016/S0020-7292\%2802\%29000632> doi: 10.1016/S0020-7292(02)00063-2

FISHER, R. A.; NEWLANDS, E. S. Gestational trophoblastic disease. Molecular and genetic studies. The Journal of reproductive medicine, v. 43, n. 1, p. 87-97, 1998. Disponível em: < https://europepmc.org/abstract/med/9475155> PMID:9475155

GONZÁlEZ AGUILERA, B., SYRIOS, P., GADISSEUR, R., LUYCKX, F., CAVALIER, E. et al. Persistent low levels of serum hCG due to heterophilic mouse antibodies: an unrecognized pitfall in the diagnosis of trophoblastic disease. Gynecological Endocrinology, v. 32, n. 6, p. 439-441, 2016. Disponível em: < https://www.tandfonline.com/doi/abs/10.3109/09513590.2015.1132303/> doi: 10.3109/09513590.2015.1132303

HAN, S. N., AMANT, F., LEUNEN, K., DEVI, U. K., NEVEN, P. et al. EP-EMA regimen (etoposide and cisplatin with etoposide, methotrexate, and dactinomycin) in a series of 18 women with gestational trophoblastic neoplasia. International Journal of Gynecological Cancer, v. 22, n. 5, p. 875-880, 2012. Disponível em: < https://www.ncbi.nlm.nih.gov/pubmed/22635033> 10.1097/IGC.0b013e31824d834d

HERnÁNDEZ, J. S., ROdRíGueZ, J. M. Z., HERRERA, M. H., PILOTO, J. M. A. Teratocarcinoma con componente de coriocarcinoma. Revista de Ciencias Médicas de Pinar del Río, v. 16, n. 1, p. 181-187, 2012. Disponível em: < http://scielo.sld.cu/scielo.php?script=sci_arttext\&pid=S1561-31942012000100019>

HSIEH, Y. T., CHOU, M. M., CHEN, H. C., TSENG, J. J. IMP1 promotes choriocarcinoma cell migration and invasion through the novel effectors RSK2 and PPME1. Gynecologic oncology, v. 131, n. 1, p. 182-190, 2013. Disponível em: < https://www.sciencedirect.com/science/article/pii/S0090825813010718/> doi: 10.1016/j.ygyno.2013.07.106

HUANG, P., YU, C., LIU, X. Q., DING, Y. B., WANG, Y. X. et al. Cytotoxicity of tubeimoside I in human choriocarcinoma JEG-3 cells by induction of cytochrome $\mathrm{C}$ release and apoptosis via the mitochondrial-related signaling pathway. International 
journal of molecular medicine, v. 28, n. 4, p. 579-587, 2011. Disponível em: < https://www.spandidos-publications.com/ijmm/28/4/579?text=abstract> 10.3892/ijmm.2011.727

JHAYYA, T. D. J., FRANCISCO, A. L. S., SILVA, C. O. S., FERREIRA, R. G. Embolia pulmonar decorrente de coriocarcinoma metastático com apresentação atípica. Jornal de Pneumologia, v. 25, n. 6, p. 340-342, 1999. Disponível em: < http://www.scielo.br/pdf/\%0D/jpneu/v25n6/v25n6a08.pdf>

JIAO, L., GHORANI, E., SEBIRE, N. J., SECKL, M. J. Intraplacental choriocarcinoma: systematic review and management guidance. Gynecologic oncology, v. 141, n. 3, p. 624-631, 2016. Disponível em: < https://www.sciencedirect.com/science/article/pii/S0090825816300828/> doi: 10.1016/j.ygyno.2016.03.026

KAJII, T.; OHAMA, K. Androgenetic origin of hydatidiform mole. Nature, v. 268, n. 5621, p. 633, 1977. Disponível em: < https://www.nature.com/articles/268633a0> doi: $10.1038 / 268633 a 0$

KAWAMURA, K., KAWAMURA, N., OKAMOTO, N., MANABE, M. Suppression of choriocarcinoma invasion and metastasis following blockade of BDNF/TrkB signaling. Cancer medicine, v. 2, n. 6, p. 849-861, 2013. Disponível em: < https://onlinelibrary.wiley.com/doi/full/10.1002/cam4.158> doi: 10.1002/cam4.158

KOHORN, E. I. Worldwide survey of the results of treating gestational trophoblastic disease. The Journal of reproductive medicine, v. 59, n. 3-4, p. 145-153, 2014. Disponível em: < https://europepmc.org/abstract/med/24724223> PMID: 24724223

LIM, W., JEONG, M., BAZER, F. W., SONG, G. Curcumin suppresses proliferation and migration and induces apoptosis on human placental choriocarcinoma cells via ERK1/2 and SAPK/JNK MAPK signaling pathways. Biology of reproduction, v. 95, n. 4, p. 83, 1-10, 2016. Disponível em: < https://academic.oup.com/biolreprod/article/95/4/83,\%201-10/2883516> doi: 10.1095/biolreprod.116.141630

LIM, W., PARK, S., BAZER, F. W., SONG, G. Apigenin reduces survival of choriocarcinoma cells by inducing apoptosis via the PI3K/AKT and ERK1/2 MAPK pathways. Journal of cellular physiology, v. 231, n. 12, p. 2690-2699, 2016. Disponível em: < https://onlinelibrary.wiley.com/doi/full/10.1002/jcp.25372> doi: 10.1002/jcp.25372

LIM, W., YANG, C., BAZER, F. W., SONG, G. Chrysophanol induces apoptosis of choriocarcinoma through regulation of ROS and the AKT and ERK1/2 pathways. Journal of cellular physiology, v. 232, n. 2, p. 331-339, 2017. Disponível em: < https://onlinelibrary.wiley.com/doi/abs/10.1002/jcp.25423> doi: 10.1002/jcp.25423

LIM, W., YANG, C., BAZER, F. W., SONG, G. Luteolin inhibits proliferation and induces apoptosis of human placental choriocarcinoma cells by blocking the $\mathrm{PISK} / \mathrm{AKT}$ pathway and regulating sterol regulatory element binding protein activity. Biology of reproduction, v. 95, n. 4, p. 82, 1-14, 2016. Disponível em: < https://academic.oup.com/biolreprod/article-abstract/95/4/82,\%201-14/2883513> doi: 10.1095/biolreprod.116.141556 
LIM, W., YANG, C., PARK, S., BAZER, F. W., SONG, G. Inhibitory effects of quercetin on progression of human choriocarcinoma cells are mediated through PI3K/AKT and MAPK signal transduction cascades. Journal of cellular physiology, v. 232, n. 6, p. 1428-1440, 2017. Disponível em: <https://onlinelibrary.wiley.com/doi/full/10.1002/jcp.25637> doi: 10.1002/jcp.25637

LURAIN, J. R. Gestational trophoblastic disease I: epidemiology, pathology, clinical presentation and diagnosis of gestational trophoblastic disease, and management of hydatidiform mole. American journal of obstetrics and gynecology, v. 203, n. 6, p. 2010.

Disponível em: https://www.sciencedirect.com/science/article/pii/S0002937810008537> doi: 10.1016/j.ajog.2010.06.073

LURAIN, John R. Gestational trophoblastic disease II: classification and management of gestational trophoblastic neoplasia. American journal of obstetrics and gynecology, v. 204, n. 1, p. 11-18, 2011. Disponível em: < https://www.sciencedirect.com/science/article/pii/S0002937810008525>. doi: 10.1016/j.ajog.2010.06.072

MAK, V. C., LEE, L., SIU, M. K., WONG, O. G., LU, X., et al. Downregulation of ASPP2 in choriocarcinoma contributes to increased migratory potential through Src signaling pathway activation. Carcinogenesis, v. 34, n. 9, p. 2170-2177, 2013. Disponível em: < https://academic.oup.com/carcin/article/34/9/2170/2463258> doi: 10.1093/carcin/bgt161

MARTÍNEZ-ORDAZ, J. L.; GÓMEZ-JIMÉNEZ, L. M.; BALLINAS-OSEGUERA, G. Coriocarcinoma metastásico a yeyuno. Reporte de tres casos. Revista de Gastroenterología de México, v. 77, n. 3, p. 143-147, 2012. Disponível em: < https://www.sciencedirect.com/science/article/pii/S0375090612000316/> doi: 10.1016/j.rgmx.2012.03.005

PATERAS, I. S., APOSTOLOPOULOU, K., NIFOROU, K., KOTSINAS, A., GORGOULIS, V. G. p57KIP2:"Kip" ing the cell under control. Molecular Cancer Research, v. 7, n. 12, p. 1902-1919, 2009. Disponível em: < http://mcr.aacrjournals.org/content/7/12/1902.short/> doi: 10.1158/1541-7786.MCR09-0317

POWLES, T., SAVAGE, P. M., STEBBING, J., SHORT, D., YOUNG, A. et al. A comparison of patients with relapsed and chemo-refractory gestational trophoblastic neoplasia. British journal of cancer, v. 96, n. 5, p. 732, 2007. Disponível em: < https://www.nature.com/articles/6603608> doi: 10.1038/sj.bjc.6603608

RAMILO, I. D. T. M., MENDINHOS, G. M., IGREJA, F. A. F. D., ALELUIA, M. C. M., Nogueira, R. M. A. N. et al. Unusual combination of gestational trophoblastic neoplasias: case report. Jornal Brasileiro de Patologia e Medicina Laboratorial, v. 50, n. 5, p. 375-378, 2014. Disponível em: <http://dx.doi.org/10.5935/16762444.20140044>. doi: 10.5935/1676-2444.20140044

REGO, F. R., BACA, D. A., SAMAMÉ, A. B., VILLANUEVA, C. C., KANO, P. L. Ruptura espontánea de metastasis hepática por coriocarcinoma. Revista de Gastroenterología del Perú, v. 30, n. 3, p. 240-245, 2010. Disponível em: 
$<$ http://www.scielo.org.pe/scielo.php?pid=S1022-

51292010000300010\&script=sci_arttext >

SÁNCHEZ ABALOS, V.; BOSCH COSTAFREDA, C.; SÁNCHEZ ABALOS, T. M. Coriocarcinoma con metástasis pulmonar. MediSan, v. 18, n. 5, p. 705-710, 2014. Disponível em: <http://dx.doi.org/10.1080/10934529.2013.815503>. doi: 10.1080/10934529.2013.815503

SECKL, M. J.; SEBIRE, N. J.; BERKOWITZ, R. S. Gestational trophoblastic disease. The Lancet, v. 376, n. 9742, p. 717-729, 2010. Disponível em: < https://www.sciencedirect.com/science/article/pii/S0140673610602802> doi: 10.1016/S0140-6736(10)60280-2

SILVA, P. A.; DA SILVA, S. R. Coriocarcinoma: um estudo de caso Coriocarcinoma: un estudio de caso Choriocarcinoma: a case study. Revista Brasileira de Enfermagem, v. 63 , n. 1, p. 148-157, 2010. Disponível em: < https://www.ingentaconnect.com/content/doaj/00347167/2010/00000063/00000001/a rt00027/> doi: 10.1590/S0034-71672010000100026

STEVENS, F. T.; KATZORKE, N.; TEMPFER, C.; KREIMER, U.; BIZJAK, G. I. et al. Gestational Trophoblastic Disorders: An Update in 2015. Geburtsh Frauenheilk, v. 75, n. 10, p. 1043-1050, 2015. Disponível em: < https://europepmc.org/articles/pmc4629994> doi: 10.1055/s-0035-1558054

TAN, Z., ZHANG, Y., DENG, J., ZENG, G., ZHANG, Y. Purified vitexin compound 1 suppresses tumor growth and induces cell apoptosis in a mouse model of human choriocarcinoma. International Journal of Gynecological Cancer, v. 22, n. 3, p. 360-366, 2012. Disponível em: < https://www.ncbi.nlm.nih.gov/pubmed/22228428> doi: 10.1097/IGC.0b013e31823de844

TEMPFER, C., HORN, L. C., ACKERMANN, S., BECKMANN, M. W., DITTRICH, R. et al. Gestational and non-gestational trophoblastic disease. guideline of the DGGG, OEGGG and SGGG (S2k Level, AWMF registry No. 032/049, december 2015). Geburtshilfe und Frauenheilkunde, v. 76, n. 02, p. 134-144, 2016. Disponível em: < https://www.ncbi.nlm.nih.gov/pmc/articles/PMC4772837/> doi: 10.1055/s-0041111788

WANG, J., SHORT, D., SEBIRE, N. J., LINDSAY, I., NEWLANDS, E. S. et al. Salvage chemotherapy of relapsed or high-risk gestational trophoblastic neoplasia (GTN) with paclitaxel/cisplatin alternating with paclitaxel/etoposide (TP/TE). Annals of Oncology, v. 19, n. 9, p. 1578-1583, 2008. Disponível em: < https://academic.oup.com/annonc/article-lookup/doi/10.1093/annonc/mdn181> doi: 10.1093/annonc/mdn181

YAZGAN, Y. U. S. U. F., ÖNCÜ, K., KAPLAN, M., TANOĞLU, A., KÜÇÜK, I. et al. Upper gastrointestinal bleeding as an initial manifestation of metastasis secondary to choriocarcinoma. The Turkish journal of gastroenterology: the official journal of Turkish Society of Gastroenterology, v. 24, n. 6, p. 565, 2013. Disponível em: < http://www.turkjgastroenterol.org/eng/makale/2830/203/Full-Text>. 10.4318/tjg.2013.0583

ZHANG, H. J., SIU, M. K., YEUNG, M. C., JIANG, L. L., MAK, V. C., et al. Overexpressed PAK4 promotes proliferation, migration and invasion of 
choriocarcinoma. Carcinogenesis, v. 32, n. 5, p. 765-771, 2011. Disponível em: < https://www.ncbi.nlm.nih.gov/pubmed/21325635> doi: 10.1093/carcin/bgr033 